УДК 541.183: 543.54

\title{
ИЗУЧЕНИЕ СОРБЦИИ ИОНОВ МЕДИ НА ПИЩЕВОМ ВОЛОКНЕ, ВЫДЕЛЕННОМ ИЗ МАСЛИЧНЫХ КУЛЬТУР ЗАУРАЛЬЯ, И БЕНТОНИТОВОЙ ГЛИНЕ
}

\author{
() Л.В. Мосталыгина", А.В. Костин, С.Н. Елизарова \\ Курганский государственный университет, ул. Гоголя, 25, Курган, 640669 \\ (Россия), e-mail: analyt@kgsu.ru
}

Изучена сорбция ионов меди на пищевых волокнах, выделенных из жмыха масличных культур Зауралья и различных формах бентонитовой глины. Проведен сравнительный анализ сорбционной активности указанных материалов. Показано, что скорость сорбции максимальна в первые 15 минут. Использование смесей пищевого волокна и глины позволяет влиять на сорбционные свойства материала.

Ключевые слова: сорбция, бентонитовая глина, пищевые волокна масличных культур, ионы меди, смеси пищевого волокна и глины.

\section{Введение}

К концу ХХ в. в мире было накоплено около 300 млн т меди [1]. Известно, что медь обладает высокой биологической активностью. Являясь одним из важных микроэлементов, в небольших количествах она необходима живому организму, но превышение физиологических норм приводит к негативному воздействию на органы желудочно-кишечного тракта, нарушению функций печени и почек. Проведенные ранее исследования [2-15] касались влияния бентонитовой глины Зырянского месторождения на содержание ионов тяжелых металлов в модельных растворах и природных объектах, а также биохимические показатели желудочного сока и дуоденального содержимого.

В настоящей работе показана возможность снижения концентрации ионов меди в модельном растворе с использованием пищевого волокна, выделенного из жмыха районированных масличных культур Зауралья, по сравнению с сорбционно активной бентонитовой глиной Зырянского месторождения Курганской области, а также впервые проведен анализ действия смесей этих сорбентов.

Сорбция на поверхности глины обусловлена следующими факторами: электростатическое притяжение, ионный обмен и комплексообразование. Поверхность глины имеет нескомпенсированный отрицательный заряд вследствие частичной замены трехвалентных катионов на двухвалентные и четырехвалентных - на трехвалентные. К ионному обмену при использовании зырянского бентонита способны ионы кальция и магния. Однако при активации глины они замещаются на ионы натрия, которые имеют более высокую способность к ионному обмену.

\footnotetext{
Мостальгина Лидия Витальевна - заведующая кафедрой физической и прикладной химии, кандидат химических наук, доцент, тел.: (3522) 46-72-73, e-mail: analyt@ kgsu.ru, mlida59@ rambler.ru

Костин Александр Вадимович - старший преподаватель кафедры физической и прикладной химии, e-mail: alexandr.v.kostin@gmail.com

Елизарова Светлана Николаевна - доцент кафедры физической и прикладной химии, кандидат биологических наук, тел.: (3522) 46-72-73, e-mail: analyt@ kgsu.ru
}

Основными же компонентами пищевых волокон являются целлюлоза, гемицеллюлоза, лигнин, пектин, альгиновая кислота, при этом указанные волокна могут иметь как однородный, так и смешанный состав, например, целлюлозолигнин, гемицеллюлозолигнин [16]. Производные целлюлозы различаются по степени полимеризации (молекулярная масса), плотности упаковки биополимерных структур, составу и структуре мономер-

\footnotetext{
* Автор, с которым следует вести переписку.
} 
ных (моносахаридных) фрагментов, образующих молекулу волокна, степени разветвления молекул; числу и виду функциональных групп, типу межмолекулярных связей [17]. Механизмы сорбции также различны. В составе молекул сахаров могут присутствовать метильные и карбоксиметильные группы, обеспечивающие отрицательный заряд на поверхности и отвечающие за катионообменные свойства пищевого волокна. Другие же функциональные группы, например, гидроксильные или этиламиноэтильные, могут нести положительный заряд и связывать анионы. Таким образом, волокно может выступать и катионо- и анионообменником в отличие от глины. Некоторые функциональные группы пищевых волокон могут образовывать водородные связи с молекулами сорбатов (если сам сорбат способен к образованию таких связей).

Особенности структуры и химического состава (наличие в составе волокон разных функциональных групп) приводят к различной субстратсвязывающей способности пищевых волокон по отношению к веществам. С другой стороны, волокна обладают неодинаковой способностью к сорбции одного и того же вещества. Очевидно, сорбционные свойства волокон, выделенных из различных культур, индивидуальны, и поэтому их необходимо детально изучать.

Связывание веществ на сорбционной матрице (глине и волокне) - процесс обратимый, поэтому возможно вытеснение с поверхности слабого сорбата более сильным. Интересные закономерности могут быть выявлены и при наличии смеси сорбентов в модельном растворе. Нами изучены композиты на основе пищевого волокна и глины.

Исследование сорбционных свойств природных материалов актуально еще и потому, что они являются экологически чистыми, действие их безвредно для окружающей среды, животных и человека.

Качественные показатели таких сорбентов могут быть повышены путем их модифицирования различными методами (химическая, термическая, механическая активация, обогащение), что позволяет создавать на их основе новые материалы с заданными свойствами.

\section{Экспериментальная часть}

Для анализа использованы глины Зырянского месторождения Курганской области, предварительно высушенные в течение 3 ч при температуре $105-110{ }^{\circ} \mathrm{C}$ и измельчённые. Мокрое обогащение (отмучивание) нативной бентонтовой глины проведено в соответствии с ГОСТ 29234.1-91 [18]. Активация бентонитовой глины кальцинированной содой проведена на предприятии ОАО «Бентонит» (Курган).

Пищевые волокна выделяли из жмыха подсолнечника однолетнего (Helianthus annuиs) сорта Иртыш (семейство астровые, регион районирования по Госреестру РФ 9 и 10 - Уральский и Западно-Сибирский). Для выделения жмыха навеску жмыха массой 3,0 г, взятую на аналитических весах, гидролизовали кипячением в 300 мл дистиллированной воды (избыток $1: 100$ ) в течение одного часа трехкратно, каждый раз меняя воду. После отстаивания и декантации пищевое волокно сушили в течение 3 ч при температуре $100^{\circ} \mathrm{C}$ в сушильном шкафу. В результате такой обработки из жмыха полностью удаляется свободный крахмал, диоксид серы и большинство растворимых в воде веществ. Содержание общего крахмала уменьшается с 10-12 до 4-5\%, а белковых веществ - на 1-2\% [19].

Сорбционную способность бентонитовой глины (БГ) и пищевых волокон (ПВ) в отношении ионов меди (II) изучали методом ионометрии на приборе рН-метр-иономер Эксперт-001-3 с использованием медь-селективного электрода марки Xc-Cu-001, электрод сравнения - хлорсеребряный в диапазоне концентраций ионов меди (II) 0,04-16 ммоль/л. Концентрацию ионов в модельном растворе измеряли через 3 ч после контакта с материалом сорбента. Во всех случаях $n=3,00 ; p=0,95 ; t_{p, f}=4,30$.

Расчет величины сорбции $a$ (ммоль/г) в условиях равновесия проводили по формуле

$$
a=\frac{\left(C_{0}-C p p \times V\right.}{m},
$$

где $\mathrm{C}_{0}$ - исходная концентрация ионов меди $\mathrm{Cu}^{2+}$, ммоль/л, $\mathrm{C}_{\mathrm{p}}$ - равновесная концентрация ионов меди $\mathrm{Cu}^{2+}$, ммоль/л, V - объем модельного раствора соли меди (II), л, m - масса сорбента, г.

Кинетику сорбции изучали методом ограниченного объема раствора [20]. В конические колбы вместимостью 100 мл помещали по 0,5г сорбента и 50 мл раствора соли меди (II) с молярной концентрацией 16 ммоль/л (1мг/мл). Время контакта составляло от 5 мин до 3 ч (статический режим). Остаточную концентрацию ионов меди (II) в модельном растворе в конкретный момент определяли ионометрически. 
Сорбционную емкость сорбента а (ммоль/г) рассчитывали по формуле

$$
a_{t}=\frac{\left(C_{0}-C_{t}\right) \times V}{m},
$$

где $\mathrm{C}_{0}$ - исходная концентрация ионов меди $\mathrm{Cu}^{2+}$, ммоль/л; $\mathrm{C}_{\mathrm{t}}-$ концентрация ионов меди $\mathrm{Cu}^{2+}$ в момент времени t, ммоль/л; V - объем модельного раствора соли меди (II), л, m - масса сорбента, г.

Погрешность эксперимента не превышала $5 \%$.

\section{Обсуждение результатов}

Влияние продолжительности контакта материала сорбента и модельного раствора на величину сорбции ионов меди (II) на образцах нативной бентонитовой глины Зырянского месторождения (НБГ), бентонитовой глины, активированной содой (АБГ), обогащенной бентонитовой глины (ОБГ) и пищевом волокне (ПВ) представлено на рисунке 1.

Для всех исследуемых сорбентов скорость сорбции ионов меди(II) максимальна в первые 15 мин контакта, затем процесс замедляется и, соответственно, через 45 (АБГ), 60 ПВ) и 75 мин (ОБГ, НБГ) устанавливается сорбционное равновесие; при этом величина $а$ наибольшая - на активированной глине и самая малая - на нативной. В течение 15 мин сорбируется от 65 (ОБГ) до 90 (АБГ) \% ионов меди.

Исследование характера сорбции показало, что в зоне низких концентраций ионов меди (II), вплоть до 0,8 ммоль/л, сорбционная способность материала примерно одинакова (рис. 2).

Однако при более высоких концентрациях ионов меди в модельном растворе нативная глина показывает минимальные сорбционные способности в отношении этого иона. Интересно, что обогащенная глина и пищевое волокно ведут себя практически одинаково по отношению к ионам меди. При повышении их концентрации (16 ммоль/л) наибольшую сорбционную способность имеет бентонитовая глина, активированная содой (АБГ). Образцы 2 и 3, как видно из рисунка 2, сопоставимы по эффективности действия (ОБГ $\approx$ ПВ).

Исследована сорбционная способность композиционных материалов на основе различных образцов глины и волокна (соотношение 1 : 1) (рис. 3-6).

Данные по сорбционным свойствам композитов на основе глины и волокна (в соотношении $1: 1$ по массе) свидетельствуют, что добавление пищевых волокон к нативной бентонитовой глине способствует увеличению сорбции ионов меди, добавление пищевых волокон к обогащенной бентонитовой глине практически не влияет на сорбцию материала, а добавление пищевых волокон к активированной бентонитовой глине снижает сорбционные свойства последней. Максимальную сорбцию из всех приготовленных материалов на основе глины и волокна в отношении ионов меди имеет смесь АБГ : ПВ = $1: 1$. Создание композиционных материалов (сорбентов) на основе ПВ и БГ позволяет, как видно из рисунков 3-6, варьировать сорбционную способность материала.

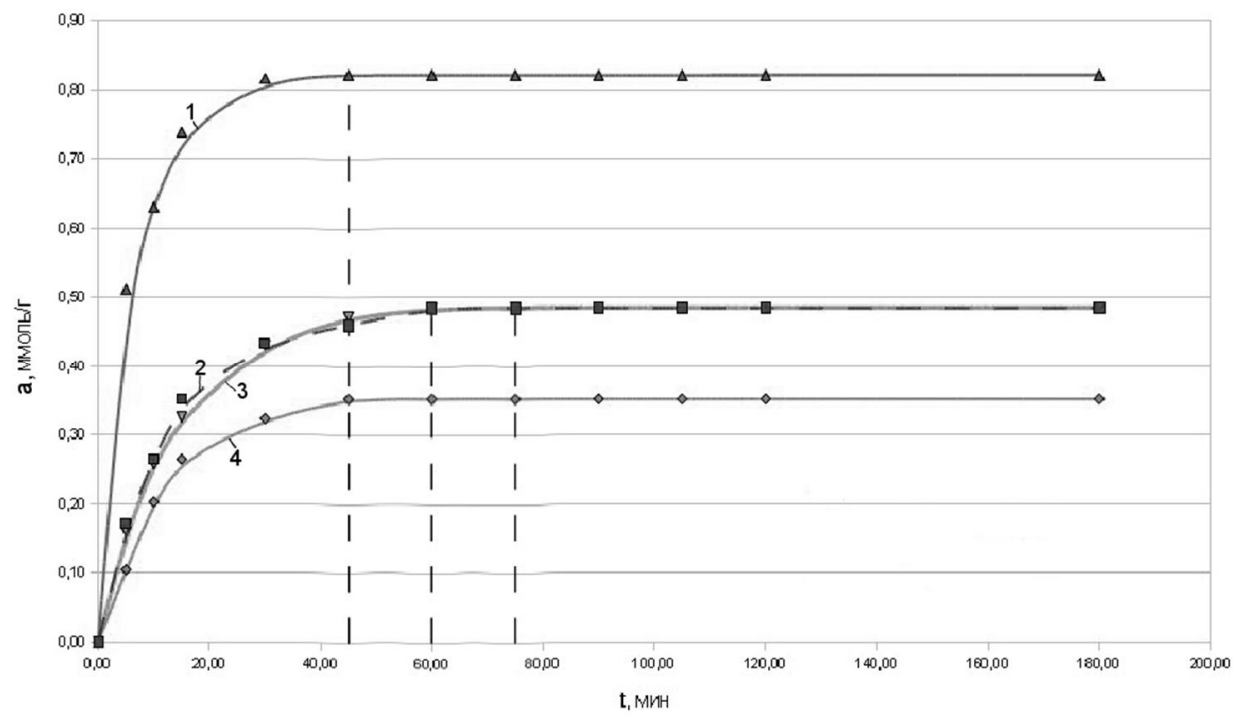

Рис. 1. Влияние продолжительности контакта модельного раствора с сорбентом АБГ (1), ПВ (2), ОБГ (3) и НБГ (4) на величину сорбции катионов меди 


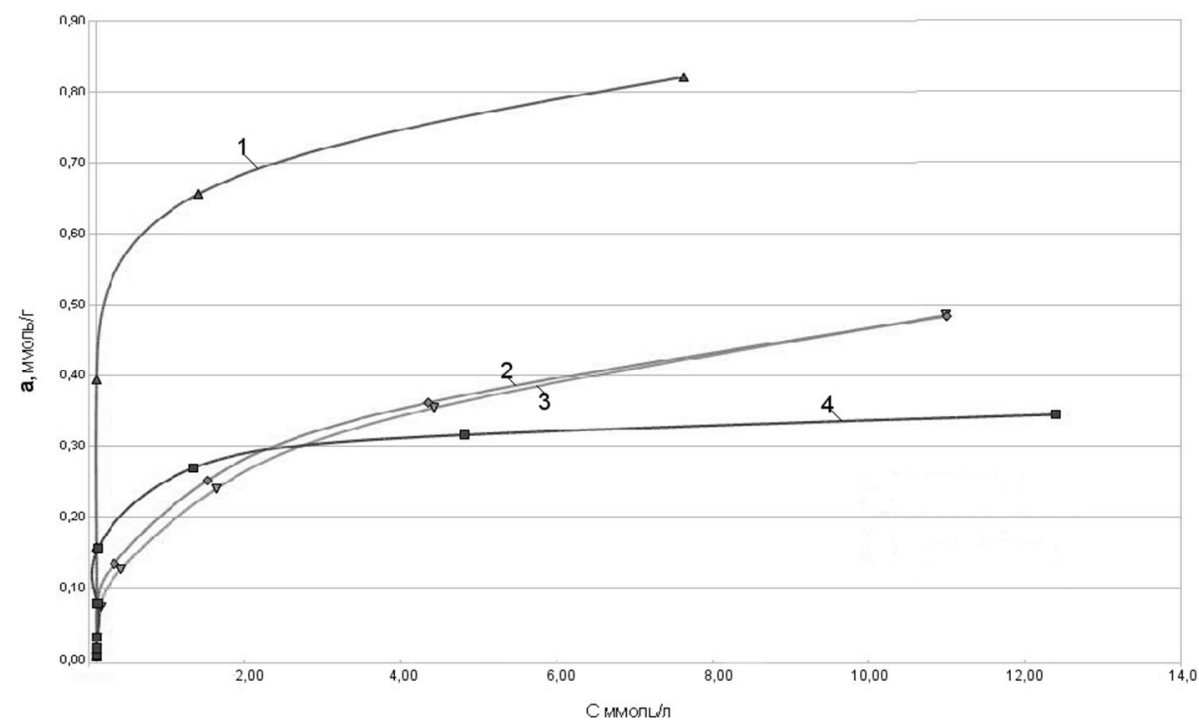

Рис. 2. Зависимость сорбции ионов меди (II) различными сорбентами от начальной концентрации ионов меди в модельном растворе: 1 -АБГ; 2 - ПВ; 3 - ОБГ; 4 - НБГ

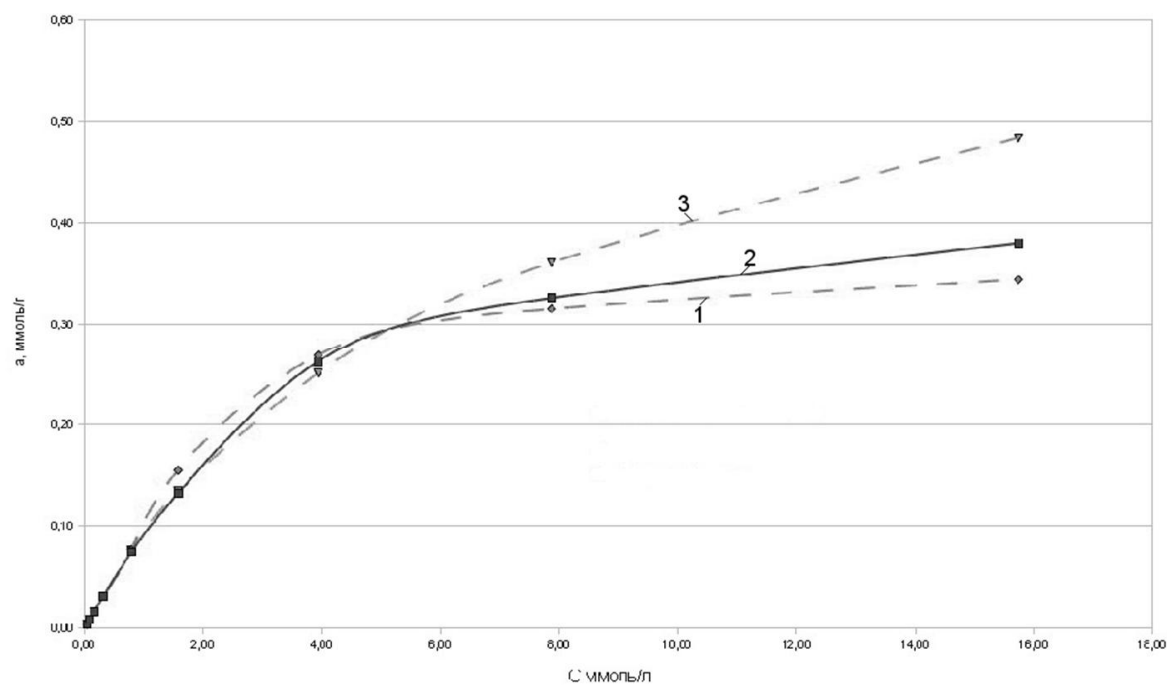

Рис. 3. Зависимость сорбции ионов меди (II) на НБГ (1), композите НБГ : ПВ = $1: 1$ (2) и ПВ (3) от начальной концентрации ионов меди в модельном растворе

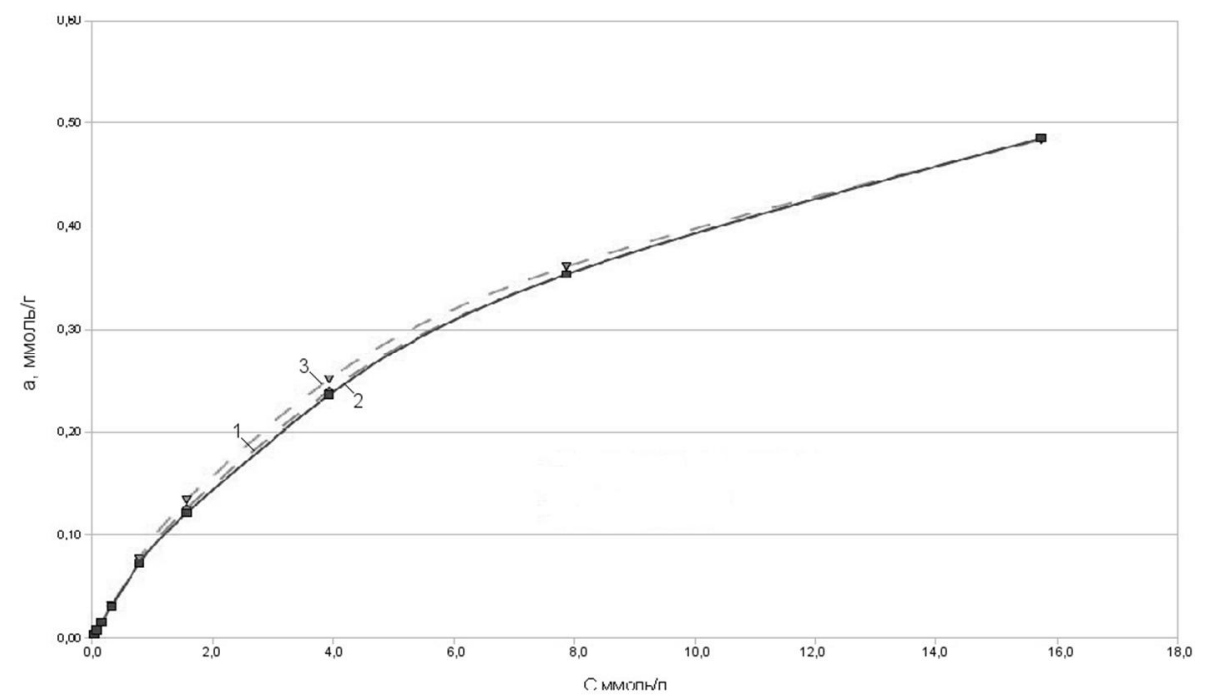

Рис. 4. Зависимость сорбции ионов меди (II) на ОБГ(1), композите ОБГ : ПВ = $1: 1$ (2) и ПВ и (3) от начальной концентрации ионов меди в модельном растворе 


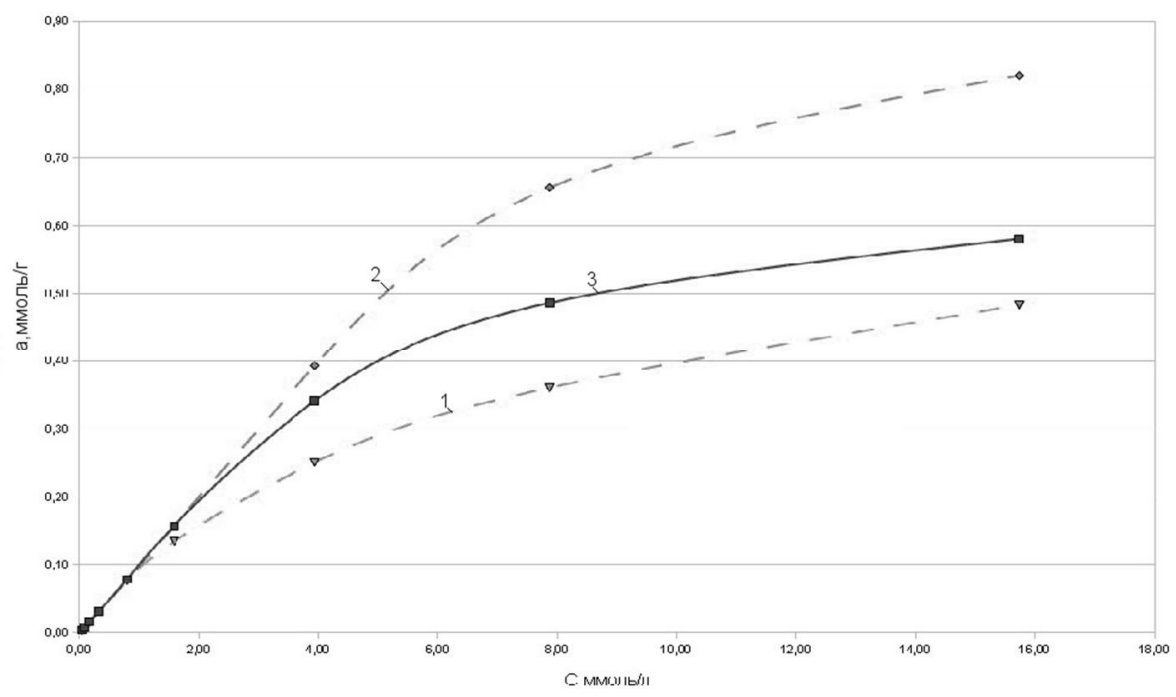

Рис. 5. Зависимость сорбции ионов меди на ПВ (1), композите АБГ : ПВ = $1: 1$ (2) и АБГ (3) от начальной концентрации ионов меди в модельном растворе

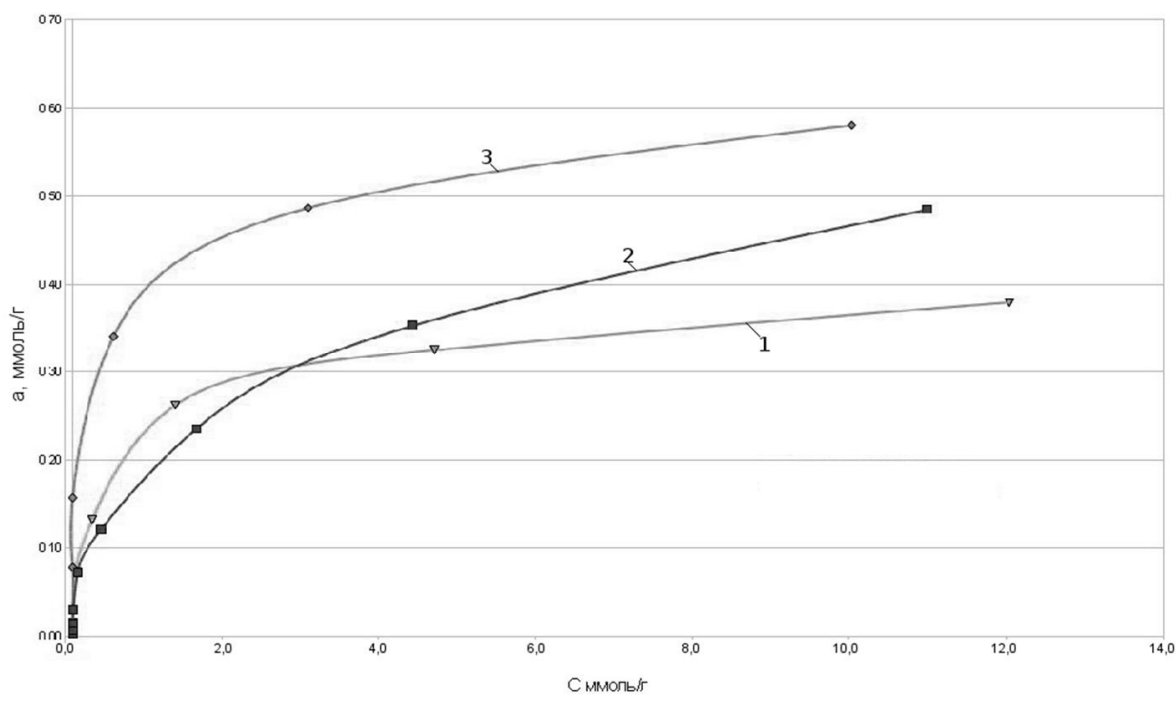

Рис. 6. Зависимость сорбции ионов меди (II) композитами НБГ : ПВ = $1: 1$ (1), ОБГ : ПВ = $1: 1$ (2), АБГ : ПВ = $1: 1$ (3) от начальной концентрации ионов меди в модельном растворе

Сорбенты в порядке увеличения сорбционной способности можно расположить в ряд: нативная бентонитовая глина < обогащенная бентонитовая глина $\approx$ пищевые волокна < активированная бентонитовая глина.

Таким образом, сорбционные свойства нативных бентонитовых глин и пищевых волокон позволяют говорить о возможности использования их в качестве эффективных природных сорбентов по отношению к ионам меди. Применение простых способов модификации способствует увеличению сорбционной способности глины, а сочетание ее с пищевыми волокнами позволяет варьировать сорбционную способность композитов в широких пределах.

\section{Выводы}

Изучена кинетика сорбции ионов меди на НБГ, АБГ, ОБГ и ПВ. Процесс сорбции протекает с различной скоростью на изучаемых сорбентах: на начальном этапе (первые 15 мин) скорость максимальна на активированной глине и минимальна на нативной глине, сорбируется от 65 (ОБГ) до 90 (АБГ) \% ионов меди. Через 45-75 мин в зависимости от природы сорбента устанавливается сорбционное равновесие.

Проведен сравнительный анализ сорбционной активности НБГ, АБГ, ОБГ, ПВ и смесей различных форм глины с пищевыми волокнами в соотношении $1: 1$ по отношению к ионам меди в интервале концентраций от 0,04 до 16 ммоль/л. Сорбция меди минимальна - на нативной бентонитовой глине - максимальна - на активированной глине. Использование смесей пищевого волокна и глины позволяет влиять на сорбционные свойства материала, уменьшая или увеличивая степень сорбции данного иона в зависимости от поставленных задач. 


\section{Список литературы}

1. Акимова Т.А., Кузьмин А.П., Хаскин В.В. Экология. Природа - Человек - Техника. М., 2007. 510 с.

2. Тихонова Л.В., Эрет В.В., Несговорова Н.П., Костин А.В. Возможности использования бентонитовых глин Зырянского месторождения Курганской области в процессах рекультивации почв // Известия высших учебных заведений. Горный журнал. 2003. №4. С. 52-55.

3. Тихонова Л.В., Костин А.В. Перспектива использования бентонитовой глины для улучшения здоровья населения // Вестник БГТУ, ІІ Международная научно-практическая конференция «Экология: образование, наука, промышленность и здоровье». Белгород, 2004. Ч. ІІ. №8. С. 171-173.

4. Елизарова С.Н., Тихонова Л.В. Использование бентонитовой глины для улучшения качества воды // Вестник БГТУ, II Международная научно-практическая конференция «Экология: образование, наука. Промышленность и здоровье». Белгород, 2004. Ч. ІІ. №8. С. 55-56.

5. Патент 2342150 (РФ). Способ уменьшения концентрации желчных кислот в желудочном соке человека / Л.В. Мосталыгина, А.В. Костин. 27.12.2008.

6. Мосталыгина Л.В., Елизарова С.Н., Костин А.В. Изменение активности амилазы бентонитовой глиной при антропогенных взаимодействиях на организм человека // Вестник Международной академии наук экологии и безопасности жизнедеятельности. СПб., 2009. Т. 14, №2. С. 88-92.

7. Костин А.В., Мосталыгина Л.В., Филистеев О.В., Бухтояров О.И. Особенности сорбции ионов никеля и меди на бентонитовой глине Зырянского месторождения Курганской области // Вестник Южно-Уральского государственного университета. Серия «Химия». 2009. №12 (145). С. 37-41.

8. Мосталыгина Л.В., Елизарова С.Н., Костин А.В. Бентонитовые глины в решении экологических проблем Зауралья // Проблемы региональной экологии. 2010. №1. С. 158-164.

9. Мосталыгина Л.В., Елизарова С.Н., Тихонова А.Ю., Костин А.В. Регуляция концентрации ионов кальция и магния природным сорбентом - бентонитовой глиной // Известия Самарского научного центра Российской академии наук. 2010. Т. 12 (33), №1(4). С. 1042-1045.

10. Бухтояров О.И., Мосталыгина Л.В., Камаев Д.Н., Костин А.В. Сорбция тяжелых металлов $\left(\mathrm{Cu}^{2+} \mathrm{Cd}^{2+,} \mathrm{Pb}^{2+}\right.$, $\mathrm{Zn}^{2+}$ ) на бентонитовой глине Зырянского месторождения Курганской области // Сорбционные и хроматографические процессы. 2011. Т. 11, вып. 4. С. 518-524.

11. Мосталыгина Л.В., Елизарова С.Н., Костин А.В. Бентонитовая глина как регулятор активности трипсина и химотрипсина в дуоденальном содержимом человека // Вестник Международной академии наук экологии и безопасности жизнедеятельности. 2011. Т. 16, №3. С. 148-150.

12. Костин А.В., Мосталыгина Л.В., Бирюкова Н.В., Бирюков М.Ф. Кинетика сорбции ионов $\mathrm{Cd}^{2+}, \mathrm{Cu}^{2+}, \mathrm{Pb}^{2+}, \mathrm{Zn}^{2+}$ на бентонитовой глине Зырянского месторождения Курганской области // Сорбенты как фактор качества жизни и здоровья : материалы IV Международной конференции. Белгород, 2012. С. 221-226.

13. Костин А.В., Мосталыгина Л.В., Бухтояров О.И. Изучение механизма сорбции ионов меди и свинца на бентонитовой глине // Сорбционные и хроматографические процессы. 2012. Т. 12. вып. 6. С. 949-957.

14. Мосталыгина Л.В., Елизарова С.Н., Костин А.В. Бентонитовые глины Зауралья: экология и здоровье человека. Курган, 2010. 149 с.

15. Мосталыгина Л.В., Елизарова С.Н., Костин А.В. Бентонитовые глины: сорбционные процессы в природоохранных технологиях. LAP LAMBERT Academic Publishing, 2011. $176 \mathrm{c}$.

16. Кокотов Ю.А., Пасечник В.А. Равновесие и кинетика ионного обмена. Л., 1970. 336 с.

17. Шатнюк Л.Н. Пищевые волокна зерновых культур: новые тенденции // Хлебопекарное производство. 2011. №2. C. 64-66.

18. ГОСТ 29234.1-91. Пески формовочные. Методы определения глинистых частиц. Введ. 1993-01-01. М., 1993. 5 с.

19. Дудкин М.С., Черно Н.К., Казанская И.С., Вайнштейн С.Г., Масик А.М. Пищевые волокна. Киев, 1988. 152 с.

20. Дудкин М.С., Щелкунов Л.Ф. Об использовании термина «пищевые волокна» и их классификация // Вопросы питания. 1997. №3. С. 42-43. 
Mostalygina L.V., Kostin A.V., Elizarova S.N. STUDY OF SORPTION OF COPPER IONS IN THE FIBER, EXTRACTED FROM OILSEEDS ZAURALYE AND BENTONITE CLAY

Kurgan State University, Gogolia st., 25, Kurgan, 640669 (Russia),e-mail: analyt@kgsu.ru

Sorption of copper ions in the fiber, extracted from oilseed cake Zauralye and various forms of bentonite clay. A comparative analysis of sorption activity of these materials. The rate of sorption is maximal in the first 15 min. Using mixtures of dietary fiber and clay allows to influence the sorption properties of the material.

Keywords: sorption, bentonite clay, dietary fiber oilseeds, copper ions, a mixture of dietary fiber and clay.

\section{References}

1. Akimova T.A., Kuz'min A.P., Khaskin V.V. Ekologiia. Priroda-Chelovek - Tekhnika. [Ecology. Nature - Human Technology.]. Moscow, 2007, 510 p. (in Russ.).

2. Tikhonova L.V., Eret V.V., Nesgovorova N.P., Kostin A.V. Izvestiia vysshikh uchebnykh zavedenii. Gornyi zhurnal, 2003, no. 4, pp. 52-55. (in Russ.).

3. Tikhonova L.V., Kostin A.V. Vestnik BGTU, II Mezhdunarodnaia nauchno-prakticheskaia konferentsiia «Ekologiia: obrazovanie, nauka, promyshlennost' $i$ zdorov'e». [Herald of BSTU, II International Scientific and Practical Conference "Ecology: education, science, industry and health"]. Belgorod, 2004, part. II. no. 8, pp. 171-173. (in Russ.).

4. Elizarova S.N., Tikhonova L.V. Vestnik BGTU, II Mezhdunarodnaia nauchno-prakticheskaia konferentsiia «Ekologiia: obrazovanie, nauka, promyshlennost' $i$ zdorov'e». [Herald of BSTU, II International Scientific and Practical Conference "Ecology: education, science, industry and health"]. Belgorod, 2004, part. II. no. 8, pp. 55-56. (in Russ.).

5. Patent 2342150 (RU). 27.12.2008. (in Russ.).

6. Mostalygina L.V., Elizarova S.N., Kostin A.V. Vestnik mezhdunarodnoi akademii nauk ekologii $i$ bezopasnosti zhiznedeiatel'nosti. [Bulletin of the International Academy of Ecology and Life Safety]. St. Petersburg, 2009, vol. 14, no. 2, pp. 88-92. (in Russ.).

7. Kostin A.V., Mostalygina L.V., Filisteev O.V., Bukhtoiarov O.I. Vestnik Iuzhno-Ural'skogo gosudarstvennogo universiteta. Seriia «Khimiia», 2009, no. 12(145), pp. 37-41. (in Russ.).

8. Mostalygina L.V., Elizarova S.N., Kostin A.V. Problemy regional'noi ekologii, 2010, no. 1, pp. 158-164. (in Russ.).

9. Mostalygina L.V., Elizarova S.N., Tikhonova A.Iu., Kostin A.V. Izvestiia Samarskogo nauchnogo tsentra Rossiiskoi akademii nauk, 2010, vol. 12(33), no. 1(4), pp. 1042-1045. (in Russ.).

10. Bukhtoiarov O.I., Mostalygina L.V., Kamaev D.N., Kostin A.V. Sorbtsionnye i khromatograficheskie protsessy, 2011, vol. 11, no. 4, pp. 518-524. (in Russ.).

11. Mostalygina L.V., Elizarova S.N., Kostin A.V. Vestnik mezhdunarodnoi akademii nauk ekologii i bezopasnosti zhiznedeiatel'nosti, 2011, vol. 16, no. 3, pp. 148-150. (in Russ.).

12. Kostin A.V., Mostalygina L.V., Biriukova N.V., Biriukov M.F. Sorbenty kak faktor kachestva zhizni i zdorov'ia: Materialy IV Mezhdunarodnoi konferentsii. [Sorbents as a factor in quality of life and health: Proceedings of the IV International Conference]. Belgorod, 2012, pp. 221-226. (in Russ.).

13. Kostin A.V., Mostalygina L.V., Bukhtoiarov O.I. Sorbtsionnye i khromatograficheskie protsessy, 2012, vol. 12, no. 6, pp. 949-957. (in Russ.).

14. Mostalygina L.V., Elizarova S.N., Kostin A.V. Bentonitovye gliny Zaural'ia: ekologiia i zdorov'e cheloveka. [Bentonite clay Zauralye: the environment and human health]. Kurgan, 2010, 149 p. (in Russ.).

15. Mostalygina L.V., Elizarova S.N.,Kostin A.V. Bentonitovye gliny: sorbtsionnye protsessy v prirodo-okhrannykh tekhnologiiakh. [Bentonite clay: sorption processes in environmental technologies]. LAP LAMBERT Academic Publishing, 2011, 176 p. (in Russ.).

16. Kokotov Iu.A., Pasechnik V.A. Ravnovesie i kinetika ionnogo obmena. [Equilibrium and kinetics of ion exchange]. Leningrad, 1970, 336 p. (in Russ.).

17. Shatniuk L.N. Khlebopekarnoe proizvodstvo, 2011, no. 2, pp. 64-66. (in Russ.).

18. GOST 29234.1-91. Peski formovochnye. Metody opredeleniia glinistykh chastits. [State Standard 29234.1-91. Sands for molding. Methods for determination of clay particles]. Moscow, 1993, 5 p. (in Russ.).

19. Dudkin M.S.,Cherno N.K., Kazanskaia I.S., Vainshtein S.G., Masik A.M. Pishchevye volokna. [Alimentary fiber]. Kiev, 1988, 152 p. (in Russ.).

20. Dudkin M.S., Shchelkunov L.F. Voprosy pitaniia, 1997, no. 3, pp. 42-43. (in Russ.).

Received March 24, 2014

Revised December 22, 2014

\footnotetext{
* Corresponding author.
} 
